\title{
Changes of storm properties in the United States: Observations and multimodel
} ensemble projections

Peng Jiang ${ }^{\mathrm{a},}$, ZhongboYu $^{\mathrm{b}}$, Mahesh R. Gautam ${ }^{\mathrm{c}}$, Feifei Yuan ${ }^{\mathrm{d}}$, and Kumud Acharya ${ }^{\mathrm{a}}$

${ }^{a}$ Division of Hydrologic Sciences, Desert Research Institute, Las Vegas, NV 89119,

\section{USA}

${ }^{\mathrm{b}}$ Department of Geoscience, University of Nevada Las Vegas, Las Vegas, NV 89154,

\section{USA}

${ }^{\mathrm{c} D i v i s i o n}$ of Flood Management, California Department of Water Resources,

$$
\text { Sacramento, CA 95821, USA }
$$

${ }^{\mathrm{d}}$ Department of Water Resources Engineering, Lund University, Lund, Sweden

\section{(1)}

.

$$
\text { *Corresponding author: }
$$

Peng Jiang, Ph.D.

\section{Email: peng.jiang@dri.edu}

Postal address: 755 E Flamingo Road, Las Vegas, NV, 89119, United States

Phone: 1 (702) 862-5388

Revised for Global and Planetary Change

March , 2016 


\section{Abstract:}

Changes in climate are likely to induce changes in precipitation characteristics including intensity, frequency, duration and patterns of events. In this paper, we evaluate the performance of multiple regional climate models (RCMs) in the North American Regional Climate Change Assessment Program (NARCCAP) to simulate storm properties including storm duration, inter-storm period, storm intensity, and within-storm patterns at eight locations in the continental US. We also investigate the future projections of them based on precipitation from NARCCAP historic runs and future runs. Results illustrate that NARCCAP RCMs are consistent with observed precipitation in the seasonal variation of storm duration and inter-storm period, but fail to simulate the magnitude. The ability to simulate the seasonal trend of average storm intensity varies among locations. Within-storm patterns from RCMs exhibit greater variability than from observed records. Comparisons between RCM-historic simulations and RCM projections indicate that there is a large variation in the future changes in storm properties. However, multi-model ensembles of the storm properties suggest that most regions of the United States will experience future changes in storm properties that includes shorter storm duration, longer inter-storm period, and larger average storm intensity.

Keywords: storm properties; NARCCAP RCMs; percentage changes; multi-model ensembles 


\section{Introduction}

Precipitation has been mostly examined in terms of total precipitation (Groisman and Easterling, 1994; Valdés-Pineda et al., 2015), intensity (Karl and Knight, 1998; Yang et al., 2010), and precipitation indices (Jiang et al., 2013b; Min et al., 2011; Shi et al., 2015; Yang et al., 2012; Yang et al., 2011) over a certain period. Few studies have contributed to the analyses of precipitation characteristics in terms of a single precipitation event, which can be characterized by the length of precipitation event (storm duration), interval between two separate precipitation events (inter-storm period), average precipitation intensity (storm intensity), and the temporal distribution of precipitation during a precipitation event (within-storm pattern). Recent studies indicate that these storm properties may change dramatically regardless of the trend of total precipitation (Easterling et al., 2000; Yu et al., 2015).

A simple example could be presented by changes in precipitation towards shorter duration higher intensity events, these changes may not be detected by simply investigating the changes in annual or monthly precipitation totals as higher intensity tends to offset the effect of shorter duration on precipitation totals. These "hidden" changes in storm properties will affect the runoff, infiltration, and evapotranspiration processes and dramatically affect the allocation of water storage and future water resources. For example, short duration, high intensity precipitation events tend to produce more runoff and less infiltration than long duration, low intensity events even if the precipitation totals are the same. Moreover, changes of these storm properties may also have profound impacts on soil erosion studies (Angel et al., 
2005; Brown and Foster, 1987; Mannaerts and Gabriels, 2000; Nyssen et al., 2005), agriculture (Adams et al., 1998; Zhang et al., 2012), ecological habitat (Peñuelas et al., 2004; Walther et al., 2002), and et al. As a result, analyses into precipitation changes should go further into the changes in storm properties.

Changes in storm properties have been touched by very few studies. Palecki et al. (2005) investigated the meteorological characteristics of storm precipitation in the United States in terms of storm total precipitation, storm duration, mean storm intensity, and maximum 15-min intensity. In their results, the western United States displays a decreasing trend in storm total precipitation and storm duration, and an increasing trend in storm intensity for most seasons, whereas the eastern United States is characterized by an increasing storm total precipitation and storm duration during winter. Samuel and Sivapalan (2008) presented a comparative analysis of observed multi-scale temporal variability of rainfall in three locations in Australia. The changes of storm durations, inter-storm periods, average storm intensity, and within-storm patterns during different climate states were examined to determine the parameter for a precipitation model. However, to our knowledge, there are even fewer studies that explored the anthropogenic impacts on the changes of storm properties due to the coarse temporal resolution of projected precipitation. Analyses on storm properties generally requires hourly or more frequently measured rainfall data (Palecki et al., 2005; Polyak et al., 1994; Tattelman and Knight, 1988), whereas most of current climate models are considered unreliable for precipitation projections shorter than one month (Prudhomme et al., 2002; Xu, 1999). Yu et al. 
(2015) presented the first attempt to investigate the changes in storm duration, interstorm period, and average storm intensity based on multiple regional climate models (RCMs) in the North American Regional Climate Change Assessment Program (NARCCAP), their results indicate that changes of storm properties are more consistent than changes of precipitation totals from different climate models. However, their analyses were limited in Nevada and California and didn't examine the changes in within-storm patterns.

This study extends the analyses from previous study by Yu et al. (2015) by further investigating changes in within-storm pattern in broader areas with different climate systems. The aim of this study is to investigate the future changes in storm properties from NARCCAAP precipitation dataset in the United States. Monthly mean storm duration, inter-storm period, storm intensity, and within storm patterns will be calculated from observed precipitation records (1971-2000), RCM-simulated historic precipitation (1971-2000), and RCM-simulated future precipitation (20412071). The ability of RCMs to simulate the storm properties will first be evaluated. Then, the percentage changes (ratio) in monthly average storm duration, inter-storm period, and storm intensity as well as long-term within-storm patterns will be examined at eight locations in the United States to investigate the changes of storm properties.

\section{Data and study locations}

\subsection{Data sources}

The observed hourly precipitation data were obtained from the National Oceanic 
and Atmospheric Administration's (NOAA's) National Climatic Data Center (NCDC) rainfall database (http://www.ncdc.noaa.gov/oa/climate/climatedata.html\#surface). Data are available between 1971 and 2000, and have less than $1 \%$ missing values for all selected stations. Missing data are filled with grid data from the Climate

Prediction Center (CPC) Hourly United States Precipitation data (http://www.esrl.noaa.gov/psd/data/gridded/data.cpc_hour.html). For accumulation periods in some stations, we reconstruct the precipitation time series using the random cascade model presented in Robinson and Sivapalan (1997) and Samuel and Sivapalan (2008).

Analyses of potential changes of storm properties for this study are based on the NARCCAP Phase II dataset (Mearns et al., 2009) which includes six RCMs and four General Circulation Models (GCMs). Ten different datasets produced by different combinations of RCMs and GCMs (drivers) have been selected for this study (Table 1). They cover a historical period (1968-2000) and future period (2039-2070) with a spatial resolution at $50 \mathrm{~km}$ and a temporal resolution of 3 hours (Some simulations may not cover the full period as the driven GCMs end at an earlier time, the actual period considered in this analysis is shown in Table 2). The historical simulations follow historical greenhouse gas (GHG) concentrations while the future simulations use the Special Report on Emissions Scenarios (SRES)-A2 global emission scenario, which considers possible developments in various fields such as economy, technology, energy, population, and land use in the $21^{\text {st }}$ century (Nakicenovic et al., 2000). The first three years (spin-up period) are discarded from the entire run for the 
storm properties analyses.

\subsection{Study locations}

Eight locations (Table 1) are selected in the U.S., which represent eight major climatic classes of the U.S. based on the Köppen-Geiger Climate Classification System (Kottek et al., 2006). Previous study has indicated that precipitation events have similar storm characteristics and seasonal variability within the same Köppen-

Geiger Climate Classification System (Jiang et al., 2013a). We assume that the selected eight locations are representative of most precipitation types in the U.S. The eight locations exhibit different characteristics in terms of average monthly storm durations, inter-storm period, storm intensity (Figure 1), and within-storm patterns (Figure 2). Las Vegas, Los Angeles, Flagstaff and Atlanta exhibit a strong seasonal pattern in terms of storm duration, while Portland, Boise, Buffalo, and St Louis display a more uniform pattern over the year. Inter-storm periods show greater seasonal variability in the western United States than in the eastern part of the United States. In Portland, Los Angeles, and Boise, summer inter-storm periods are longer than other seasons over the year, which indicates a dry summer due to the domination of the subtropical high pressure system (Loik et al., 2004). Most locations experience the same seasonal pattern of the average storm intensity, with higher intensity in the summer and lower intensity in the winter. However, Portland and Los Angeles witness an opposite phase of average storm intensity pattern compared to the other locations, which is caused by the typical Mediterranean Climate (Di Castri, 1973). Atlanta shows a greater variability of within-storm pattern 
157

158

159

160

161

162

163

164

165

166

167

as indicated by the wider range of $10 \%$ and $90 \%$ percentile curve in Figure 2.

\section{Methods}

\subsection{Extract modeled time series for each location}

The modeled time series for each station from the RCMs precipitation dataset is extracted using a common technique, which uses the nearest grid point (Jiang et al., 2013a; Mishra et al., 2012; Schär et al., 2004) for making inferences at small regional scales or specific location from coarser climate models scales (Anagnostopoulos et al., 2010; Georgakakos, 2003; Koutsoyiannis et al., 2008). In this paper, we extract RCM time series of the grid point closest to the selected location and create hourly precipitation time series from RCM 3-h precipitation using a uniform random distribution (Jiang et al., 2013a).

\subsection{Identify an independent precipitation storm event}

Identification of an independent storm event is the building block for our analyses. Some common methods include arbitrary separation (Huff, 1967), autocorrelation method (Wenzel and Voorhees, 1981), and procedure based on rank correlation coefficients (Grace and Eagleson, 1966). In this paper, we identify the independent storm events in each location using a criterion of a specified minimum dry period (6h) (Jiang et al., 2013a; Menabde and Sivapalan, 2000; Palecki et al., 2005; Restrepo-Posada and Eagleson, 1982; Robinson and Sivapalan, 1997; Samuel and Sivapalan, 2008). A threshold of " $0.1 \mathrm{~mm}$ " is used to determine a dry interval to alleviate the impact of "drizzling" problems (Chen et al., 1996; Dai, 2006) in NARCCAP precipitation simulations. Then a storm event is identified if it is 
separated from the preceding and succeeding precipitation by the minimum dry period or more.

\subsection{Calculations on monthly storm duration, inter-storm period, and intensity} as well as long-term within-storm patterns

After storm events are identified, monthly mean storm duration, inter-storm period, and storm intensity are calculated from observed precipitation records, RCMsimulated historic precipitation, and RCM-simulated future precipitation using the equations described as below:

$$
\begin{gathered}
S D_{\text {mean }}=\sum_{i=1}^{n} S D_{i} / n \\
I P_{\text {mean }}=\sum_{i=1}^{n} I P_{i} / n \\
S I_{\text {mean }}=\sum_{i=1}^{n} S D_{i} * S I_{i} / \sum_{i=1}^{n} S D_{i}
\end{gathered}
$$

where $S D_{i}, I P_{i}$, and $S I_{i}$ are storm duration, inter-storm period, and average storm intensity for the $i t h$ storm event out of $n$ storm events in the selected month. $S D_{\text {mean }}$, $I P_{\text {mean }}$, and $S I_{\text {mean }}$ are monthly mean of storm duration, inter-storm period, and average storm intensity, respectively. Rather than use the ensemble mean precipitation time series for the determination of ensemble mean storm properties, we calculate the ensemble mean value by averaging the storm properties obtained from each individual RCM precipitation outputs.

Within-storm patterns are characterized using the idea of cumulative normalized mass curves (Chow et al., 1988; Huff, 1967; Robinson and Sivapalan, 1997; Samuel and Sivapalan, 2008). A normalized cumulative mass curve is defined by

$$
H\left(t^{*}\right)=\frac{1}{\langle i\rangle t_{r}} \int_{0}^{t} i\left(t^{\prime}\right) d t^{\prime}
$$


Where $t^{*}=t / t_{r}\left(0 \leqslant t^{*} \leqslant 1\right),\langle i\rangle$ is the mean precipitation intensity for the storm,

202

$i(t)$ is the instantaneous precipitation intensity at time $t$, and $t_{r}$ is storm duration.

Three sets of mass curves (10-, 50-, 90-percent cumulative probabilities of occurrence) are generated for the analyses.

\subsection{Evaluations of NARCCAP RCMs on simulating the storm properties and}

\section{future projections of storm properties}

Using Equation (1), (2), and (3), monthly storm duration, inter-storm period, and average storm intensity could be calculated during the history period from both observed station precipitation time series and RCM historic simulated precipitation time series and future period from RCM future simulated precipitation time series.

With Equation (4), cumulative normalized mass curves could be determined for the selected two periods.

The ability of the NARCCAP RCMs to simulate storm properties is evaluated by comparing the monthly mean storm duration, inter-storm period, average storm intensity, and within-storm patterns determined from observed records with those from RCM historic runs during the overlapping period. The future projections of long-term monthly storm properties are investigated by computing percentage changes of projected storm properties (results from RCM future runs) from the simulated storm properties (results from RCM historic runs) for the monthly storm duration, inter-storm period, and average storm intensity based on each individual RCM. To reduce climate noise in model predictions, we also compare the multimodel ensemble of these storm properties between the two periods using the simple 
average method (Houghton et al., 2001b). Changes of within-storm patterns are examined during the whole historic period and future period, as comparisons of within-storm patterns in monthly statistics are not feasible due to small sample of storm events during certain month.

\section{Results}

\subsection{Model performance on simulating the storm properties}

The ensemble means of storm properties across 10 NARCCAP RCMs from historic simulations show longer storm duration, shorter inter-storm period, and lower storm intensity than those from observed precipitation records in all locations (Figure 3). This is not surprising due to the higher frequency of moisture convection in climate models than in nature where convective inhibition processes allow atmospheric instability to accumulate before intense convection starts (Dai, 2006). This problem is usually described as the "drizzling problems" in precipitation simulations by most large scale climate models, which tend to produce precipitation events with longer durations and lower intensity than those determined from observed records (Chen et al., 1996; Dai, 2006; Dai et al., 1999; Dai and Trenberth, 2004; Osborn and Hulme, 1998; Sun et al., 2006). However, some exceptions exist for inter-storm period, where July and August RCM-simulated inter-storm periods are longer than observed in Las Vegas and Flagstaff, and winter (December-February) simulated inter-storm periods are longer than observed in Portland. For average monthly storm intensity, RCMs show different abilities at different locations (Figure 4) in simulating the seasonal trends. In Atlanta, St Louis, and Buffalo, the RCM- 
simulated average storm intensity matches the observed average storm intensity very well in terms of seasonal trend. In the other five locations, the RCM-simulated average storm intensity fails to represent the high average storm intensity during summer and fall (April-October). It may be due to the NARCCAP RCMs' inability to simulate local convective heat transport effects in the intermountain west (Jiang et al., 2013a). For within-storm patterns, individual NARCCAP RCMs simulate a large range of within-storm patterns (Figure 5). In Portland, Los Angeles, and Atlanta, the RCM-simulated within-storm patterns succeed to match the observed within-storm patterns, while in other locations, the 10 percent and 90 percent percentile curves from the RCMs are wider than those from observed records, indicating that the RCMs tend to simulate a greater variability of within-storm patterns in these locations.

\subsection{Future percentage changes in storm properties from NARCCAP RCMs}

\subsubsection{Projected changes from individual RCMs}

Individual NARCCAP RCMs in the future period simulate a large range of changes in storm duration (Figure 6), inter-storm period (Figure 7), and average storm intensity (Figure 8). Percentage changes in storm duration display the largest uncertainty during summer period in the southwestern United States including Las Vegas, Los Angeles, and Flagstaff. The inter-storm period exhibits greater uncertainty than storm duration in general. The widest range is seen in Las Vegas, where projected percentage changes of inter-storm period in June ranges from 20 percent decrease to 100 percent increase. For average storm intensity, the uncertainty 
range is even greater than both storm duration and inter-storm period. The most extreme projected change is seen in Flagstaff in July, which ranges from 25\% decrease to $175 \%$ increase. However, the large range of changes is caused by only one model, which implies probable outliers. The model uncertainties in projected changes of average storm intensity show a regional pattern. The western United States experiences greater model uncertainties in summer and fall, while the eastern United States experiences greater model uncertainty in winter and spring. For the within-storm patterns, the curve ranges determined from RCM-historic runs (historic curve ranges) match well with curve ranges determined from RCM-future runs (future curve ranges), except in the 10 percentile curve ranges in Boise and Los Angeles. The historic curve range for 10 percentile curve is wider than future curve range for 10 percentile curve (Figure 9).

\subsubsection{Projected changes from multi-model ensembles}

Results from individual RCM help to understand the uncertainty of changes in the future (Giorgi and Francisco, 2000; Visser et al., 2000; Zhu et al., 2013). On the other hand, using multi-model ensembles tend to increase the skill, reliability and consistency of model forecasts (Doblas-Reyes et al., 2003; Tebaldi and Knutti, 2007; Yun et al., 2003).

Projected future storm duration calculated from multi-model ensembles shows a general decreasing trend in the future (Figure 10). Larger values exist in certain months, mostly during winter (December-January-February) and spring (MarchApril-May) except in Los Angeles, where summer experiences largest increase in 
storm duration. In Pacific Northwest (Portland, and Boise) and eastern United States (Buffalo, St Louis, and Atlanta), the largest decrease is seen during the summer period (June-July-October), while in southwestern United States (Las Vegas, Los Angeles, and Flagstaff), the largest decrease is seen during spring.

Projected inter-storm period displays a more consistent increasing trend among different locations and months compared to the historic values. However, Portland, Los Angeles, and Atlanta show a decrease in projected values mostly during late summer and early fall. But these decreases are less obvious compared to the generally noticed increases in the projected values. The largest increase among different months is regionally dependent as the eastern United States and Pacific Northwest experience largest increase during summer while southwestern United States experiences largest increase during spring (Figure 11).

The average storm intensity exhibits a general increase except in Portland, where the most obvious changes are characterized by projected decrease in summer. The eastern United States displays more consistently increase than the western United States. Changes in average storm intensity have more obvious seasonal pattern in the eastern United States than the west. In eastern United States, the largest changes could be found during the winter period (Figure 12).

Mass curves of three levels from RCM-historical simulations almost lined up together with those from RCM-future simulations (Figure 9), indicating that changes of long-term average within-storm patterns are not obvious under future climate conditions. 


\subsubsection{Relationships between changes of total storm precipitation and storm} properties

The RCMs project an obvious decrease in total storm precipitation during the summer period in Pacific Northwest region and the spring period in the southwest. However, decrease in total precipitation during this period is characterized by different changes in storm properties (Table 3). In Portland, Los Angeles, and Las Vegas, the decrease in total precipitation could be explained by a decrease in both storm duration and average storm intensity. However, in Boise, the decrease in total precipitation is caused by less frequent storm events with shorter storm duration as indicated by an obvious decrease in storm duration and an increase in inter-storm period. The increase in storm intensity can't offset the effect of shorter storm duration on total precipitation.

In eastern United States, the RCMs project a decrease in the summer period and an increase in the other seasons in terms of total storm precipitation. During the period characterized by increasing precipitation, the consistent and larger percentage increase in storm intensity indicate that changes in storm intensity explain the changes in total precipitation. During the period with decreasing total precipitation, decrease in storm duration explains the decrease in total precipitation.

\section{Discussions and Conclusions}

In this study, we present an evaluation of the ability of multiple NARCCAP RCMs to simulate storm properties including storm duration, inter-storm period, storm intensity, and within-storm patterns. We also investigate the potential changes 
of these storm properties by comparing the statistics from10 RCMs' historic runs and $10 \mathrm{RCMs}$ ' future runs. Our analyses highlight the changes of storm properties under future climate conditions at eight locations in the continental United States, which confirm and extend finding from previous studies (Easterling et al., 2000; Jiang et al., 2013a; Palecki et al., 2005; Webster et al., 2005; Yu et al., 2015).

The evaluation of the ability of NARCCAP RCMs to simulate the storm properties is consistent with the previous study by Jiang (2013a) who conducted a thorough diagnostics on GCMs/RCMs' skills in simulating the multi-scale temporal variability of precipitation derived from observed records in the southwestern United States. The results confirm their conclusion that NARCCAP RCMs show consistencies with the observed precipitation in the seasonal changes in storm duration and inter-storm period, but fail to simulate the magnitude. The inability of RCMs to simulate the magnitude of average storm intensity may be due to the bias between RCM grid data and observed data, which could be improved by various methods (Li et al., 2010; Piani et al., 2010; Wood et al., 2002). However, bias correction of grid precipitation data does not help to improve the inability of RCMs to simulate the seasonal trend and the high average storm intensity during summer and fall in the western United States, where summer is characterized by small amount of precipitation with high intensity. It is worth noting that the RCMs could simulate the seasonal trend of average storm intensity in the eastern United States. The difference of model performance in different regions may be due to the NARCCAP RCMs' inability to simulate local convective heat transport effects and 
North American Monsoon system which significantly affects the precipitation in the southwestern United States (Adams and Comrie, 1997; Douglas et al., 1993; Higgins et al., 1997).

As a result, investigations of changes in storm properties using NARCCAP RCMs can only be limited to percentage changes (changes in ratio) of RCMprojected storm properties to RCM-simulated storm properties. We investigate the future changes of storm properties based on the NARCCAP RCMs driven at A2 emission scenario. We find that individual RCMs exhibit great uncertainty in the percentage changes in storm duration, inter-storm period, and average storm intensity. The ensemble means of storm properties across 10 future NARCCAP RCM projections show generally shorter storm duration, longer inter-storm period, and higher storm intensity than those from 10 historical NARCCAP RCM simulations in all locations. It means that storm events in the United States. will happen less frequently with shorter duration and higher intensity in the future climate conditions, which is consistent with former studies with a conclusion that global warming will accelerate the hydrologic cycle (Barnett et al., 2005; Houghton et al., 2001a) and induce more intense precipitation events in United States (Groisman et al., 2005; Karl and Knight, 1998; Min et al., 2011).

Previous studies (Cayan et al., 2010; Seager et al., 2007) have indicated that the southwestern United States will suffer from an imminent transition to a more arid climate, which is further confirmed by the projected decreasing storm duration and increasing inter-storm period from multi-model ensemble means of NARCCAP 
377 RCMs. However, the high intensity storm events exhibit a disproportionate change 378 with total precipitation. As a result, the southwestern United States will be marked by drier and more extreme climates.

The development of various downscale schemes upon current GCM data has led to an increasing number of RCM outputs for regional impact studies. How should we narrow the number of climate inputs and choose the most appropriate downscaled 
Development (EPA). The authors acknowledge that the views herein are that of the

authors only and not related the organizations they are affiliated to.

\section{Reference}

Adams, D.K. and Comrie, A.C., 1997. The north American monsoon. Bulletin of the American Meteorological Society, 78(10), 2197-2213.

Adams, R.M., Hurd, B.H., Lenhart, S. and Leary, N., 1998. Effects of global climate change on agriculture: an interpretative review. Climate Research, 11(1), 19-30.

Anagnostopoulos, G., Koutsoyiannis, D., Christofides, A., Efstratiadis, A. and Mamassis, N., 2010. A comparison of local and aggregated climate model outputs with observed data. Hydrological Sciences Journal-Journal des Sciences Hydrologiques, 55(7), 1094-1110.

Angel, J.R., Palecki, M.A. and Hollinger, S.E., 2005. Storm precipitation in the United States. Part II: Soil erosion characteristics. Journal of Applied Meteorology, 44(6), 947-959.

Barnett, T.P., Adam, J.C. and Lettenmaier, D.P., 2005. Potential impacts of a warming climate on water availability in snow-dominated regions. Nature, 438(7066), 303-309.

Brown, L. and Foster, G., 1987. Storm erosivity using idealized intensity distributions. Transactions of the ASAE-American Society of Agricultural Engineers, 30, 379-386.

Cayan, D.R. et al., 2010. Future dryness in the southwest US and the hydrology of the early 21st century drought. Proceedings of the National Academy of Sciences, 107(50), 21271-21276.

Chen, M., Dickinson, R.E., Zeng, X. and Hahmann, A.N., 1996. Comparison of precipitation observed over the continental United States to that simulated by a climate model. Journal of climate, 9(9), 2233-2249.

Chow, V.T., Maidment, D.R. and Mays, L.W., 1988. Applied hydrology. Tata McGraw-Hill Education, New York.

Dai, A., 2006. Precipitation characteristics in eighteen coupled climate models. Journal of Climate, 19(18), 4605-4630.

Dai, A., Giorgi, F. and Trenberth, K.E., 1999. Observed and model - simulated diurnal cycles of precipitation over the contiguous United States. Journal of Geophysical Research: Atmospheres (1984-2012), 104(D6), 6377-6402.

Dai, A. and Trenberth, K.E., 2004. The diurnal cycle and its depiction in the Community Climate System Model. Journal of climate, 17(5), 930-951.

Di Castri, F., 1973. Climatographical comparisons between Chile and the western coast of North America, Mediterranean type ecosystems. Springer, pp. 21-36.

Doblas-Reyes, F., Pavan, V. and Stephenson, D., 2003. The skill of multi-model seasonal forecasts of the wintertime North Atlantic Oscillation. Climate dynamics, 21(5-6), 501-514.

Douglas, M.W., Maddox, R.A., Howard, K. and Reyes, S., 1993. The mexican monsoon. Journal of climate, 6(8), 1665-1677.

Easterling, D.R. et al., 2000. Climate extremes: observations, modeling, and impacts. science, 289(5487), 2068-2074.

Georgakakos, K.P., 2003. Probabilistic climate-model diagnostics for hydrologic and water resources 
impact studies. Journal of Hydrometeorology, 4(1), 92-105.

Giorgi, F. and Francisco, R., 2000. Evaluating uncertainties in the prediction of regional climate change. Geophysical Research Letters, 27(9), 1295-1298.

Grace, R.A. and Eagleson, P.S., 1966. synthesis of short-time-increment rainfall sequences. Report (Massachusetts Institute of Technology. Hydrodynamics Laboratory); no. 91.

Groisman, P.Y. and Easterling, D.R., 1994. Variability and trends of total precipitation and snowfall over the United States and Canada. Journal of climate, 7(1), 184-205.

Groisman, P.Y. et al., 2005. Trends in intense precipitation in the climate record. Journal of climate, 18(9), 1326-1350.

Higgins, R., Yao, Y. and Wang, X., 1997. Influence of the North American monsoon system on the US summer precipitation regime. Journal of climate, 10(10), 2600-2622.

Houghton, J. et al., 2001a. IPCC, 2001: Climate Change 2001: The Scientific Basis. Contribution of Working Group I to the Third Assessment Report of the Intergovernmental Panel on Climate Change. Cambridge, United Kingdom, New York, USA, Cambridge University Press, 881, 9.

Houghton, J.T. et al., 2001b. Climate change 2001: the scientific basis, 881 . Cambridge University Press Cambridge.

Huff, F.A., 1967. Time distribution of rainfall in heavy storms. Water Resources Research, 3(4), $1007-$ 1019.

Jiang, P., Gautam, M.R., Zhu, J. and Yu, Z., 2013a. How well do the GCMs/RCMs capture the multiscale temporal variability of precipitation in the Southwestern United States? Journal of Hydrology, 479, 75-85.

Jiang, P., Yu, Z. and Gautam, M.R., 2013b. Pacific and Atlantic Ocean influence on the spatiotemporal variability of heavy precipitation in the western United States. Global and Planetary Change, 109, 38-45.

Karl, T.R. and Knight, R.W., 1998. Secular trends of precipitation amount, frequency, and intensity in the United States. Bulletin of the American Meteorological Society, 79(2), 231-241.

Kottek, M., Grieser, J., Beck, C., Rudolf, B. and Rubel, F., 2006. World map of the Köppen-Geiger climate classification updated. Meteorologische Zeitschrift, 15(3), 259-263.

Koutsoyiannis, D., Efstratiadis, A., Mamassis, N. and Christofides, A., 2008. On the credibility of climate predictions. Hydrological Sciences Journal, 53(4), 671-684.

Li, H., Sheffield, J. and Wood, E.F., 2010. Bias correction of monthly precipitation and temperature fields from Intergovernmental Panel on Climate Change AR4 models using equidistant quantile matching. Journal of Geophysical Research, 115(D10101).

Loik, M.E., Breshears, D.D., Lauenroth, W.K. and Belnap, J., 2004. A multi-scale perspective of water pulses in dryland ecosystems: climatology and ecohydrology of the western USA. Oecologia, 141(2), 269-281.

Mannaerts, C. and Gabriels, D., 2000. Rainfall erosivity in Cape Verde. Soil and Tillage Research, 55(3), 207-212.

Mearns et al., 2009. A regional climate change assessment program for North America. Eos, Transactions American Geophysical Union, 90(36), 311.

Menabde, M. and Sivapalan, M., 2000. Modeling of rainfall time series and extremes using bounded random cascades and levy - stable distributions. Water Resources Research, 36(11), 32933300.

Min, S.-K., Zhang, X., Zwiers, F.W. and Hegerl, G.C., 2011. Human contribution to more-intense 
precipitation extremes. Nature, 470(7334), 378-381.

Mishra, V., Dominguez, F. and Lettenmaier, D.P., 2012. Urban precipitation extremes: How reliable are regional climate models? Geophysical Research Letters, 39(3).

Nakicenovic, N. et al., 2000. Special report on emissions scenarios: a special report of Working Group III of the Intergovernmental Panel on Climate Change, Pacific Northwest National Laboratory, Richland, WA (US), Environmental Molecular Sciences Laboratory (US).

Nyssen, J. et al., 2005. Rainfall erosivity and variability in the Northern Ethiopian Highlands. Journal of Hydrology, 311(1), 172-187.

Osborn, T.J. and Hulme, M., 1998. Evaluation of the European daily precipitation characteristics from the atmospheric model intercomparison project. International Journal of Climatology, 18(5), 505-522.

Palecki, M.A., Angel, J.R. and Hollinger, S.E., 2005. Storm precipitation in the United States. Part I: meteorological characteristics. Journal of Applied Meteorology, 44(6), 933-946.

Peñuelas, J. et al., 2004. Complex spatiotemporal phenological shifts as a response to rainfall changes. New Phytologist, 161(3), 837-846.

Piani, C., Haerter, J. and Coppola, E., 2010. Statistical bias correction for daily precipitation in regional climate models over Europe. Theoretical and Applied Climatology, 99(1-2), 187-192.

Polyak, I., North, G.R. and Valdes, J.B., 1994. Multivariate space-time analysis of PRE-STORM precipitation. Journal of Applied Meteorology, 33(9), 1079-1087.

Restrepo-Posada, P.J. and Eagleson, P.S., 1982. Identification of independent rainstorms. Journal of Hydrology, 55(1), 303-319.

Robinson, J.S. and Sivapalan, M., 1997. Temporal scales and hydrological regimes: implications for flood frequency scaling. Water Resources Research, 33(12), 2981-2999.

Samuel, J.M. and Sivapalan, M., 2008. A comparative modeling analysis of multiscale temporal variability of rainfall in Australia. Water Resources Research, 44(7), W07401.

Schär, C. et al., 2004. The role of increasing temperature variability in European summer heatwaves. Nature, 427(6972), 332-336.

Seager, R. et al., 2007. Model projections of an imminent transition to a more arid climate in southwestern North America. Science, 316(5828), 1181-1184.

Shi, P. et al., 2015. Spatial Distribution and Temporal Trends in Precipitation Concentration Indices for the Southwest China. Water Resources Management, 29(11), 3941-3955.

Sun, Y., Solomon, S., Dai, A. and Portmann, R.W., 2006. How often does it rain? Journal of Climate, 19(6), 916-934.

Tattelman, P. and Knight, R.W., 1988. Analyses of 1-min Rain Rates Extracted from Weighing Raingage Recordings. Journal of Applied Meteorology, 27, 928-938.

Tebaldi, C. and Knutti, R., 2007. The use of the multi-model ensemble in probabilistic climate projections. Philosophical Transactions of the Royal Society A: Mathematical, Physical and Engineering Sciences, 365(1857), 2053-2075.

Valdés-Pineda, R. et al., 2015. Spatio-temporal trends of precipitation, its aggressiveness and concentration, along the Pacific coast of South America $\left(36^{\circ}-49^{\circ} \mathrm{S}\right)$. Hydrological Sciences Journal(just-accepted).

Visser, H., Folkert, R., Hoekstra, J. and De Wolff, J., 2000. Identifying key sources of uncertainty in climate change projections. Climatic Change, 45(3-4), 421-457.

Walther, G.-R. et al., 2002. Ecological responses to recent climate change. Nature, 416(6879), 389- 
395.

Webster, P.J., Holland, G.J., Curry, J.A. and Chang, H.-R., 2005. Changes in tropical cyclone number, duration, and intensity in a warming environment. Science, 309(5742), 1844-1846.

Wenzel, H.G. and Voorhees, M.L., 1981. An evaluation of the urban design storm concept. University of Illinois, Water Resources Center.

Wood, A.W., Maurer, E.P., Kumar, A. and Lettenmaier, D.P., 2002. Long - range experimental hydrologic forecasting for the eastern United States. Journal of Geophysical Research, 107(D20).

Yang, T. et al., 2012. Multi-model ensemble projections in temperature and precipitation extremes of the Tibetan Plateau in the 21st century. Global and Planetary Change, 80, 1-13.

Yang, T. et al., 2010. Regional frequency analysis and spatio-temporal pattern characterization of rainfall extremes in the Pearl River Basin, China. Journal of Hydrology, 380(3), 386-405.

Yang, T. et al., 2011. Changes of climate extremes in a typical arid zone: Observations and multimodel ensemble projections. Journal of Geophysical Research: Atmospheres (19842012), 116(D19).

Yu, Z., Jiang, P., Gautam, M.R., Zhang, Y. and Acharya, K., 2015. Changes of seasonal storm properties in California and Nevada from an ensemble of climate projections. Journal of Geophysical Research: Atmospheres, 120(7), 2676-2688.

Yun, W., Stefanova, L. and Krishnamurti, T., 2003. Improvement of the multimodel superensemble technique for seasonal forecasts. Journal of climate, 16(22), 3834-3840.

Zhang, Q., Sun, P., Singh, V.P. and Chen, X., 2012. Spatial-temporal precipitation changes (1956-2000) and their implications for agriculture in China. Global and Planetary Change, 82, 86-95.

Zhu, J., Forsee, W., Schumer, R. and Gautam, M., 2013. Future projections and uncertainty assessment of extreme rainfall intensity in the United States from an ensemble of climate models. Climatic Change, 1-17. 
TABLE CAPTIONS

557

Table 1. Selected locations and corresponding climate types based on Köppen-Geiger Climate Classification System in NARCCAP dataset

Table 3. Changes of monthly storm properties* and total precipitation calculated from RCM-future precipitation records compared to those calculated from RCM-historic precipitation records

564 


\section{FIGURE CAPTIONS}

Figure 1.Observed storm properties including monthly mean storm duration (bottom Y axis, units: h), storm intensity (middle $\mathrm{Y}$ axis, units: $\mathrm{mm} / \mathrm{h}$ ), and inter-storm period (top Y axis, units: h) at selected locations

Figure 2.Mass Curves determined from the observed records for the selected locations

Figure 3.Monthly mean storm duration and inter-storm period from observed records and ensemble mean of the $10 \mathrm{RCM}$-simulated historic precipitation time series. Top bars are inter-storm period, and bottom bars are storm duration

Figure 4.Average monthly storm intensity from observed records and ensemble mean of the $10 \mathrm{RCM}$-simulated historic precipitation time series. Left $\mathrm{Y}$ axis is observed storm intensity, right $\mathrm{Y}$ axis is for RCM average

Figure 5.Mass Curves determined from the observed records and 10 NARCCAP RCM-simulated precipitation time series. The color gradient denotes the simulation ranges from RCMs

Figure 6. Box Plots of percentage changes of storm duration from 10 individual RCMs. Percentage changes $(\%)=\left[100\left(\mathrm{SD}_{\text {future }}-\mathrm{SD}_{\text {historic }}\right) / \mathrm{SD}_{\text {historic }}\right]$ where $\mathrm{SD}_{\text {historic }}$ is the ensemble mean storm duration from historic runs and $\mathrm{SD}_{\text {future }}$ is the ensemble mean storm duration from future runs

Figure 7. Box plots of percentage changes of inter-storm period from 10 individual RCMs. Percentage changes $(\%)=\left[100\left(\mathrm{IP}_{\text {future }}-\mathrm{IP}_{\text {historic }}\right) / \mathrm{IP}_{\text {historic }}\right]$ where $\mathrm{IP}_{\text {historic }}$ is the ensemble mean inter-storm period from historic runs and $\mathrm{IP}_{\text {future }}$ is the ensemble mean inter-storm period from future runs 
587

588

589

590

591

592

593

594

595

596

597

598

599

600

601

602

603

604

605

606

607

608

Figure 8. Percentage changes of average storm intensity from 10 individual RCMs.

Percentage changes $(\%)=\left[100\left(\mathrm{SI}_{\text {future }}-\mathrm{SI}_{\text {historic }}\right) / \mathrm{SI}_{\text {historic }}\right]$ where $\mathrm{SI}_{\text {historic }}$ is the ensemble mean storm intensity from historic runs and $\mathrm{SI}_{\text {future }}$ is the ensemble mean storm intensity from future runs

Figure 9. Mass Curves determined from the observed records and 10 NARCCAP RCM-simulated precipitation time series

Figure 10. Percentage changes (in \%) of ensemble mean storm duration between historic and future runs. Percentage changes $(\%)=\left[100\left(\mathrm{SD}_{\text {future }}{ }^{-}\right.\right.$ $\mathrm{SD}_{\text {historic }} / \mathrm{SD}_{\text {historic }}$. Lines in the upper axis is $\mathrm{SD}_{\text {historic }}$; circles in the upper axis is $\mathrm{SD}_{\text {future }}$

Figure 11. Percentage changes (in \%) of ensemble mean inter-storm period between historic and future runs. Percentage changes $(\%)=\left[100\left(\mathrm{IP}_{\text {future }}{ }^{-}\right.\right.$ $\left.\left.\mathrm{IP}_{\text {historic }}\right) / \mathrm{IP}_{\text {historic }}\right]$. Lines in the upper axis is $\mathrm{IP}_{\text {historic }}$; circles in the upper axis is $\mathrm{IP}_{\text {future }}$

Figure 12. Percentage changes (in \%) of ensemble mean storm intensity between historic and future runs. Percentage changes $(\%)=\left[100\left(\mathrm{SI}_{\text {future }}{ }^{-}\right.\right.$ $\left.\mathrm{SI}_{\text {historic }}\right) / \mathrm{SI}_{\text {historic }}$. Lines in the upper axis is $\mathrm{SI}_{\text {historic }}$; Circles in the upper axis is $\mathrm{SI}_{\text {future }}$ 
609 Table 1 Selected locations and corresponding climate types based on the Köppen-Geiger 610 Climate Classification System

611

\begin{tabular}{llll}
\hline Station & City & Climate type & Climate code \\
\hline 356751 & Portland & Marine westcoast climate & Cfb \\
101022 & Boise & semi-arid steppe Climate & Bsk \\
264436 & Las Vegas & Mid latitude Desert Climate & Bwh \\
045115 & Los Angeles & Mediterranean Climate & Csa \\
023010 & Flagstaff & High land (alpine) Climate & Dsa/Dsb \\
301012 & Buffalo & Humid Continental Climate (cold summer) & Dfb \\
237455 & ST Louis & Humid Continental Climate (warm summer) & Dfa \\
090451 & Atlanta & humid sub-tropical Climate & Cfa \\
\hline
\end{tabular}

612

613

614 
Table 2 Regional climate models, the corresponding driver GCMs, and time periods in NARCCAP dataset.

\begin{tabular}{|c|c|c|c|c|}
\hline $\mathrm{RCM} / \mathrm{GCM}$ & $\mathrm{RCM}$ & GCM Driver & Historic Period & Future Period \\
\hline $\mathrm{CRCM}+\mathrm{CCSM}$ & Canadian Regional Climate Model & Community Climate System Model & 1971-1998 & $2041-2068$ \\
\hline $\mathrm{CRCM}+\mathrm{CGCM} 3$ & Canadian Regional Climate Model & Third Generation Coupled GCM & 1971-1999 & 2041-2069 \\
\hline $\mathrm{ECP} 2+\mathrm{GFDL}$ & $\begin{array}{l}\text { Experimental Climate Prediction Center } \\
\text { Regional Spectral Model }\end{array}$ & Geophysical Fluid Dynamics Laboratory GCM & $1971-2000$ & $2041-2070$ \\
\hline HRM3+GFDL & Hadley Regional Model 3 & Geophysical Fluid Dynamics Laboratory GCM & $1971-2000$ & $2041-2070$ \\
\hline HRM3+HadCM3 & Hadley Regional Model 3 & Hadley Centre Coupled Model Version 3 & $1971-2000$ & $2041-2070$ \\
\hline MM5I+CCSM & Mesoscale Model ISU Version & Community Climate System Model & 1971-1999 & $2041-2069$ \\
\hline MM5I+HadCM3 & Mesoscale Model ISU Version & Hadley Centre Coupled Model Version 3 & $1971-2000$ & $2041-2070$ \\
\hline RCM3+CGCM3 & $\begin{array}{l}\text { UC Santa Cruz Regional Climate Model } \\
\text { Version3 }\end{array}$ & Third Generation Coupled GCM & $1971-2000$ & $2041-2070$ \\
\hline RCM3+GFDL & $\begin{array}{l}\text { UC Santa Cruz Regional Climate Model } \\
\text { Version3 }\end{array}$ & Geophysical Fluid Dynamics Laboratory GCM & $1971-2000$ & $2041-2070$ \\
\hline WRFG+CCSM & Weather Research and Forecasting Model & Community Climate System Model & 1971-1999 & 2041-2069 \\
\hline WRFG+CGCM3 & Weather Research and Forecasting Model & Third Generation Coupled GCM & $1971-2000$ & $2041-2070$ \\
\hline
\end{tabular}


Table 3 Changes of monthly storm properties* and total precipitation calculated from RCM-future precipitation records compared to those calculated from RCM-historic precipitation records

\begin{tabular}{|c|c|c|c|c|c|c|c|c|c|c|c|c|}
\hline & \multicolumn{12}{|c|}{ Month } \\
\hline & Jan & Feb & Mar & Apr & May & Jun & Jul & Aug & Sep & Oct & Nov & Dec \\
\hline \multicolumn{13}{|c|}{ Portland } \\
\hline TP & -0.03 & -0.08 & 0.01 & 0.02 & 0.13 & -0.09 & -0.18 & -0.23 & 0.05 & 0.02 & 0.07 & 0.05 \\
\hline SD & -0.03 & -0.06 & -0.09 & -0.05 & 0.07 & -0.07 & -0.12 & -0.13 & -0.06 & 0.01 & 0.01 & 0.05 \\
\hline IP & 0.08 & -0.03 & 0.08 & 0.04 & -0.01 & 0.09 & 0.04 & 0.03 & 0.00 & 0.00 & -0.01 & 0.05 \\
\hline SI & 0.04 & -0.04 & 0.08 & 0.06 & 0.06 & $\begin{array}{c}-0.04 \\
\text { Boise }\end{array}$ & -0.13 & -0.12 & 0.07 & 0.02 & 0.04 & 0.05 \\
\hline TP & 0.02 & -0.01 & 0.01 & -0.02 & 0.10 & -0.11 & -0.22 & -0.23 & 0.08 & -0.03 & 0.05 & 0.16 \\
\hline SD & -0.03 & -0.03 & -0.09 & -0.05 & 0.04 & -0.06 & -0.09 & -0.11 & -0.03 & -0.02 & 0.02 & -0.01 \\
\hline IP & 0.07 & 0.16 & 0.09 & 0.09 & 0.02 & 0.06 & 0.12 & 0.29 & 0.08 & 0.08 & 0.11 & 0.02 \\
\hline SI & 0.08 & 0.10 & 0.14 & 0.06 & 0.12 & 0.01 & 0.07 & 0.10 & 0.16 & 0.07 & 0.10 & 0.16 \\
\hline \multicolumn{13}{|c|}{ Los Angeles } \\
\hline $\mathrm{TP}$ & 0.19 & -0.05 & -0.09 & -0.31 & -0.30 & 0.05 & 0.35 & 0.11 & 0.06 & -0.15 & -0.18 & -0.10 \\
\hline SD & -0.01 & -0.07 & -0.03 & -0.09 & -0.03 & 0.09 & 0.07 & 0.04 & 0.01 & -0.11 & -0.08 & 0.02 \\
\hline IP & 0.02 & 0.06 & 0.08 & 0.15 & 0.27 & 0.02 & -0.08 & 0.01 & -0.09 & 0.15 & 0.11 & 0.06 \\
\hline SI & 0.20 & 0.04 & -0.01 & -0.08 & -0.30 & -0.25 & 0.81 & -0.07 & 0.00 & -0.17 & -0.02 & -0.05 \\
\hline \multicolumn{13}{|c|}{ Las Vegas } \\
\hline $\mathrm{TP}$ & 0.16 & 0.02 & -0.07 & -0.35 & -0.44 & -0.23 & -0.06 & 0.01 & 0.01 & -0.12 & -0.04 & -0.08 \\
\hline SD & 0.01 & -0.02 & -0.03 & -0.15 & -0.15 & -0.10 & -0.12 & -0.11 & -0.03 & -0.09 & -0.04 & -0.01 \\
\hline IP & 0.08 & 0.10 & 0.15 & 0.19 & 0.43 & 0.20 & 0.02 & 0.19 & 0.14 & 0.20 & 0.13 & 0.08 \\
\hline SI & 0.25 & 0.06 & 0.11 & -0.11 & -0.11 & -0.06 & 0.19 & 0.02 & 0.01 & -0.03 & 0.13 & -0.02 \\
\hline \multicolumn{13}{|c|}{ Flagstaff } \\
\hline $\mathrm{TP}$ & 0.14 & -0.10 & -0.14 & -0.31 & -0.34 & -0.04 & 0.01 & 0.07 & -0.03 & 0.00 & -0.01 & -0.11 \\
\hline SD & -0.02 & -0.03 & -0.09 & -0.14 & -0.11 & 0.11 & -0.05 & -0.02 & 0.04 & -0.07 & -0.02 & -0.04 \\
\hline IP & 0.12 & 0.12 & 0.19 & 0.21 & 0.41 & 0.20 & 0.15 & 0.03 & 0.13 & 0.14 & 0.14 & 0.09 \\
\hline SI & 0.29 & 0.02 & 0.07 & -0.08 & 0.02 & 0.22 & 0.26 & 0.12 & -0.04 & 0.02 & 0.19 & 0.02 \\
\hline \multicolumn{13}{|c|}{ St Louis } \\
\hline $\mathrm{TP}$ & 0.11 & 0.08 & 0.03 & 0.04 & 0.08 & -0.03 & -0.22 & -0.07 & 0.01 & 0.05 & 0.04 & 0.17 \\
\hline SD & 0.04 & 0.01 & -0.01 & -0.03 & 0.00 & -0.09 & -0.08 & -0.08 & -0.06 & 0.01 & -0.01 & 0.02 \\
\hline IP & 0.04 & 0.06 & 0.02 & 0.05 & 0.02 & 0.09 & 0.20 & 0.06 & 0.04 & 0.06 & 0.04 & 0.05 \\
\hline SI & 0.12 & 0.12 & 0.08 & 0.10 & 0.12 & 0.06 & -0.05 & 0.07 & 0.08 & 0.17 & 0.10 & 0.20 \\
\hline \multicolumn{13}{|c|}{ Buffalo } \\
\hline $\mathrm{TP}$ & 0.17 & 0.10 & 0.09 & 0.08 & 0.11 & -0.05 & -0.05 & -0.04 & 0.05 & -0.04 & 0.07 & 0.15 \\
\hline SD & 0.00 & -0.05 & 0.01 & 0.03 & 0.02 & -0.12 & -0.12 & -0.12 & -0.04 & -0.05 & 0.03 & -0.01 \\
\hline IP & 0.05 & 0.09 & 0.05 & 0.03 & 0.03 & 0.11 & 0.06 & 0.07 & 0.06 & 0.05 & 0.09 & 0.05 \\
\hline SI & 0.19 & 0.19 & 0.12 & 0.08 & 0.14 & 0.09 & 0.02 & 0.06 & 0.10 & 0.05 & 0.14 & 0.23 \\
\hline \multicolumn{13}{|c|}{ Atlanta } \\
\hline $\mathrm{TP}$ & 0.03 & 0.10 & 0.07 & 0.05 & 0.06 & -0.06 & -0.01 & 0.03 & 0.08 & 0.07 & 0.02 & 0.09 \\
\hline SD & -0.04 & -0.06 & -0.01 & -0.03 & -0.01 & -0.13 & -0.15 & -0.18 & -0.06 & 0.03 & 0.06 & 0.03 \\
\hline IP & 0.03 & 0.07 & 0.01 & 0.08 & 0.04 & 0.11 & 0.02 & -0.05 & -0.07 & 0.01 & 0.03 & 0.02 \\
\hline SI & 0.03 & 0.23 & 0.09 & 0.10 & 0.09 & 0.05 & 0.07 & 0.10 & 0.11 & 0.08 & 0.05 & 0.07 \\
\hline
\end{tabular}

* TP represents total precipitation, SD represents storm duration, IP represents inter-storm period, and SI represents storm intensity. 


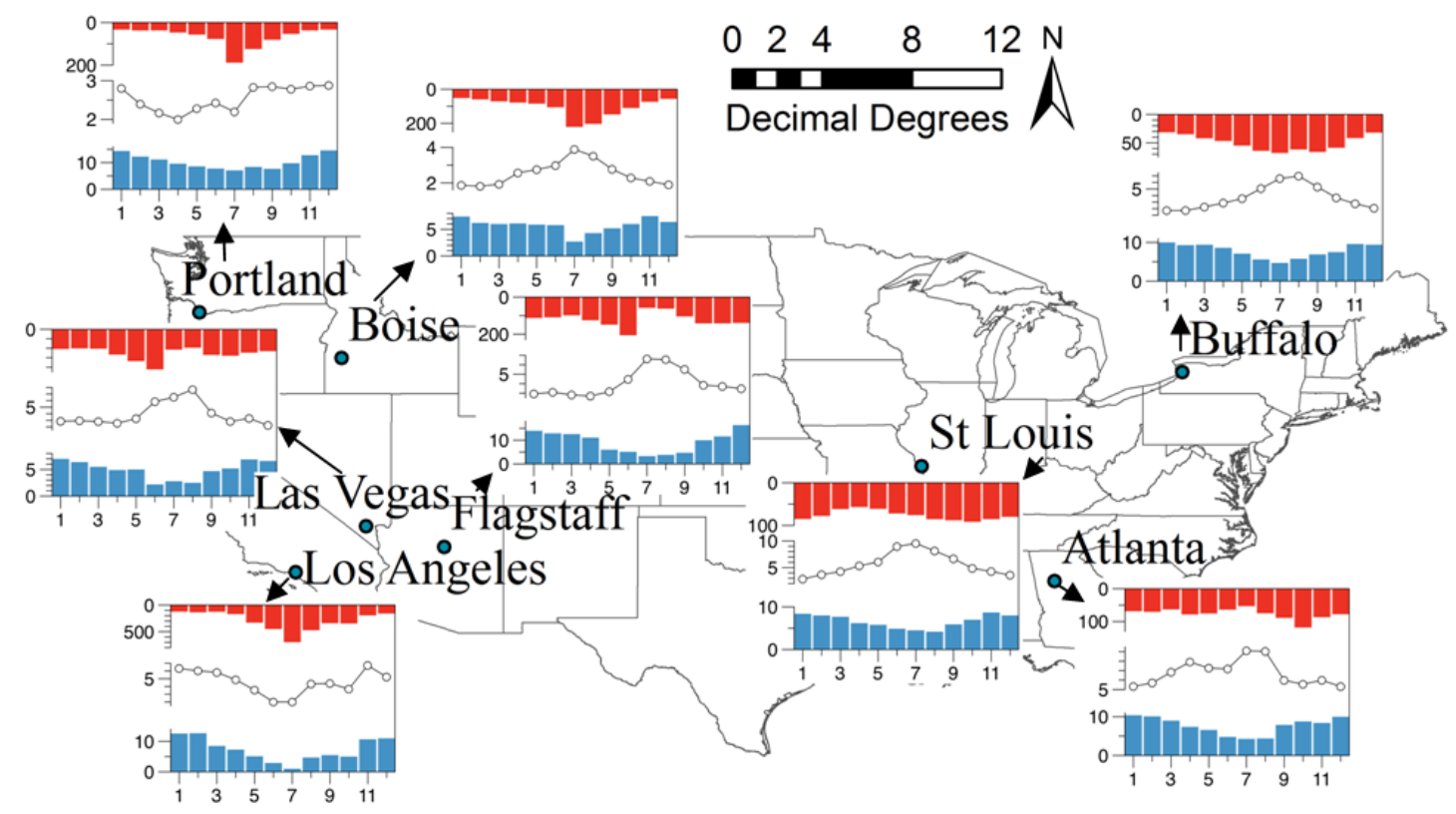

Figure 1.Observed storm properties including monthly mean storm duration (bottom $\mathrm{Y}$ axis, units: h), storm intensity (middle $\mathrm{Y}$ axis, units: $\mathrm{mm} / \mathrm{h}$ ), and inter-storm period (top Y axis, units: h) at selected locations 


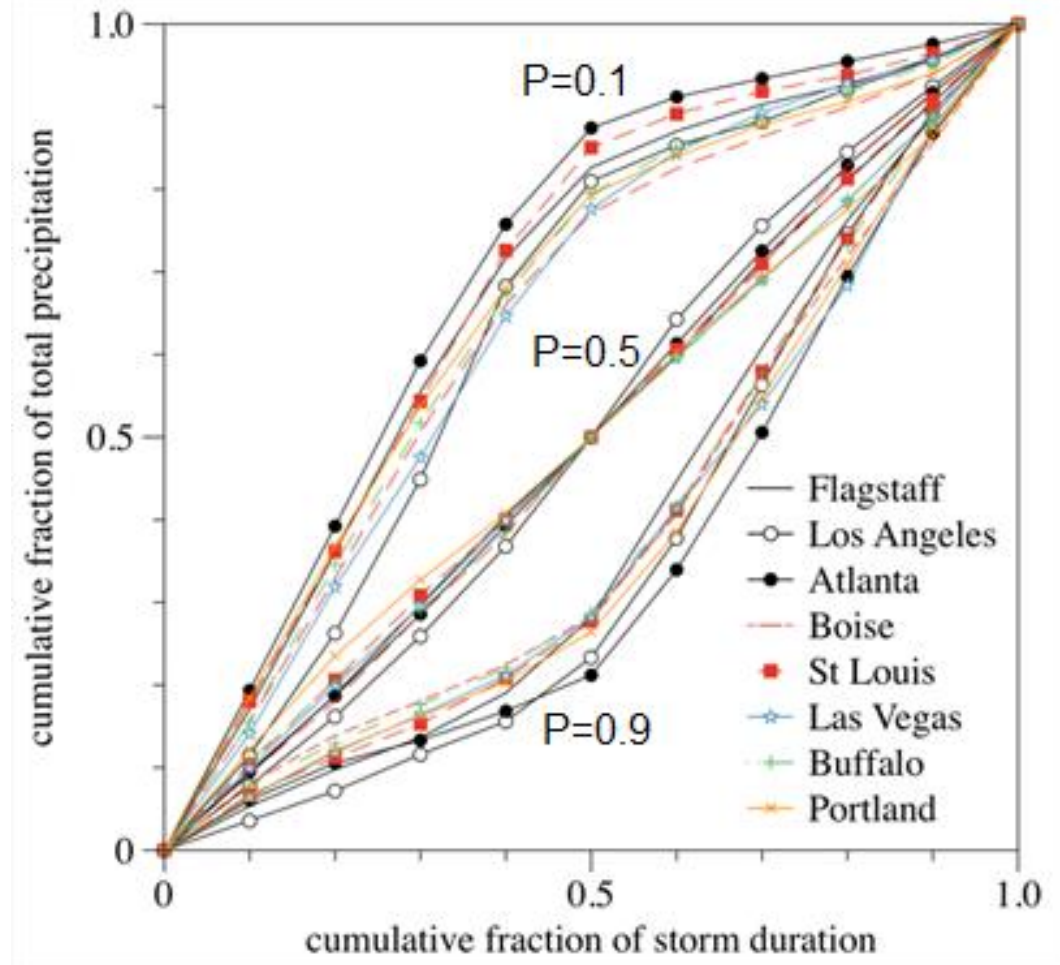

Figure 2.Mass Curves determined from the observed records for the selected locations. 

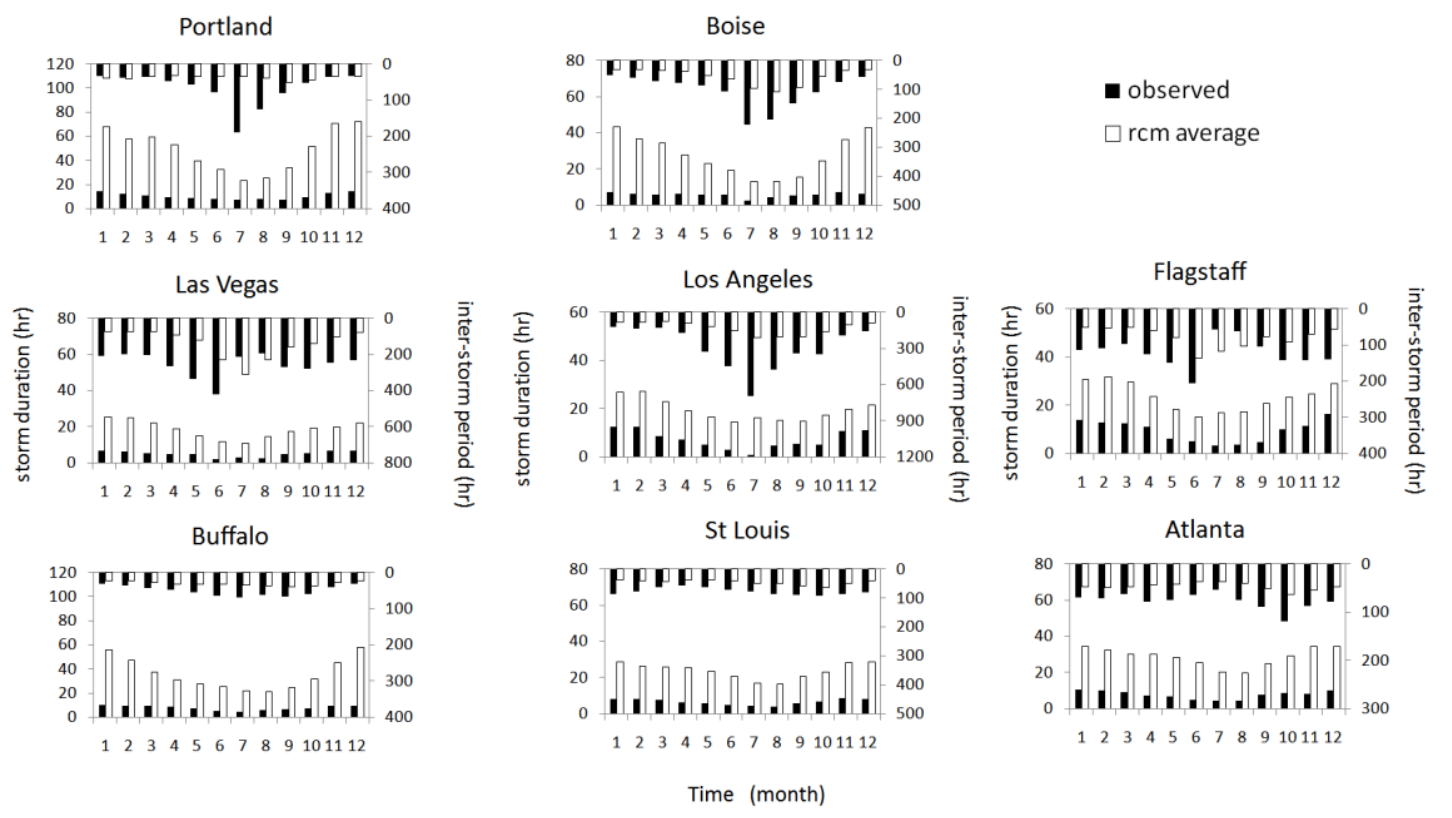

Figure 3. Monthly mean storm duration and inter-storm period from observed records and ensemble mean of the 10 RCM-simulated historic precipitation time series. Top bars are inter-storm period, and bottom bars are storm duration. 

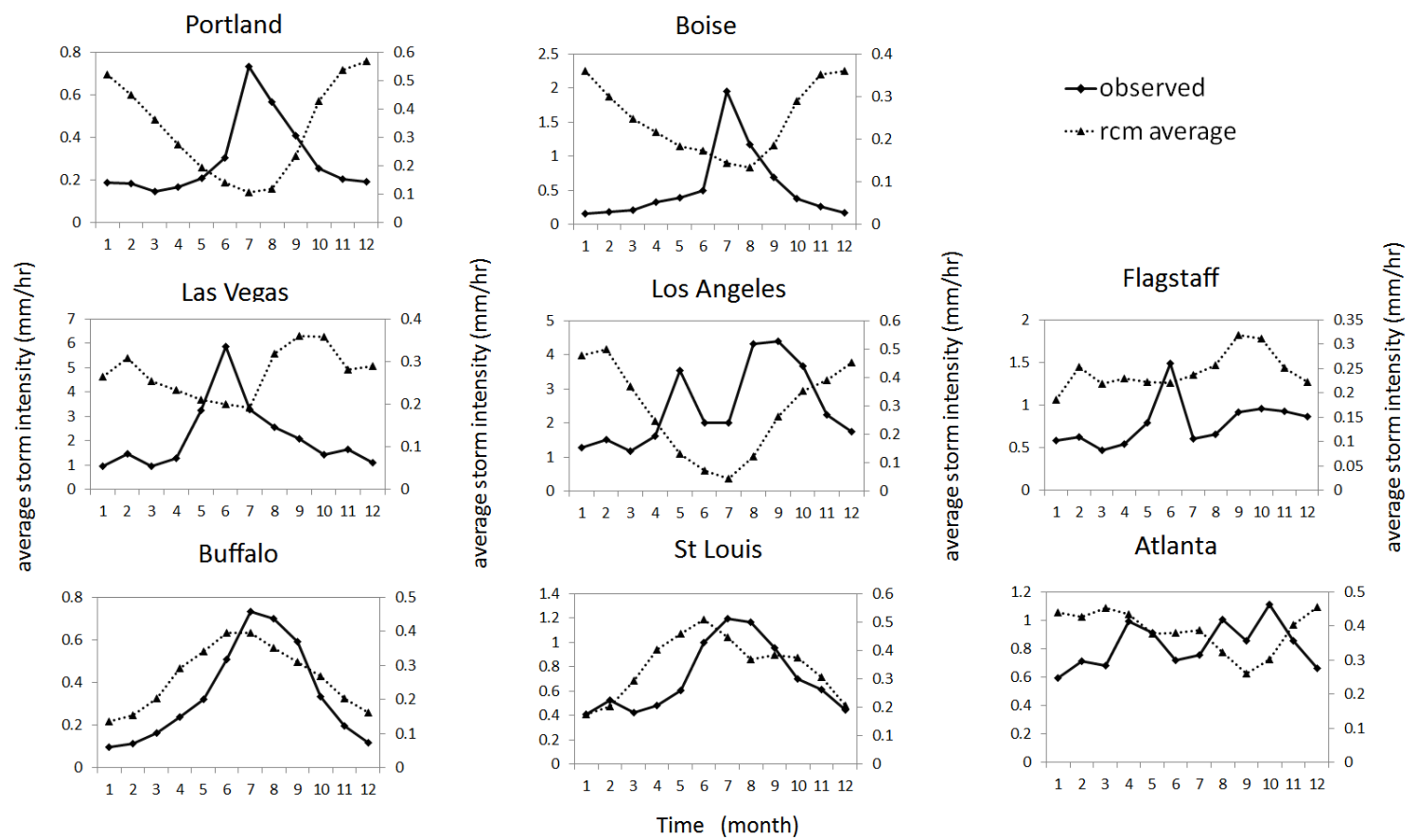

Figure 4.Average monthly storm intensity from observed records and ensemble mean of the $10 \mathrm{RCM}$-simulated historic precipitation time series. Left $\mathrm{Y}$ axis is observed storm intensity, right $\mathrm{Y}$ axis is for RCM average. 

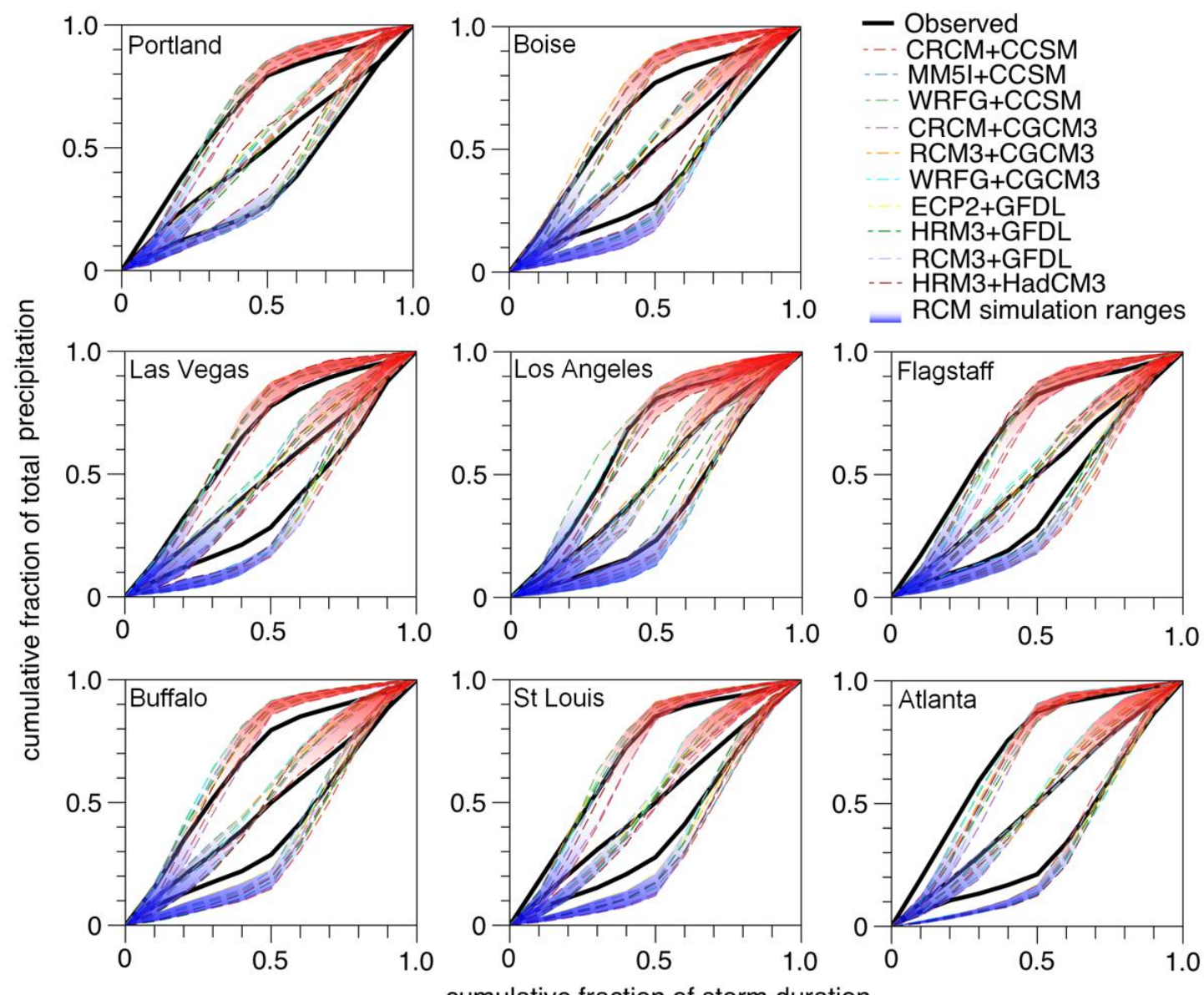

Figure 5.Mass Curves determined from the observed records and 10 NARCCAP RCM-

simulated precipitation time series. The color gradient denotes the simulation ranges from RCMs. 

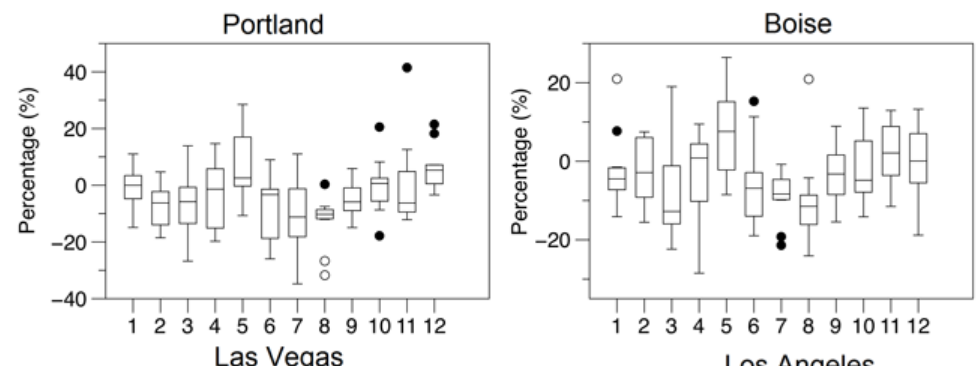

T Mean+1.5*Std Dev

Mean-1.5^Std Dev

Mean+Std Dev

Mean

Mean-Std Dev

- Outliers

- Extremes
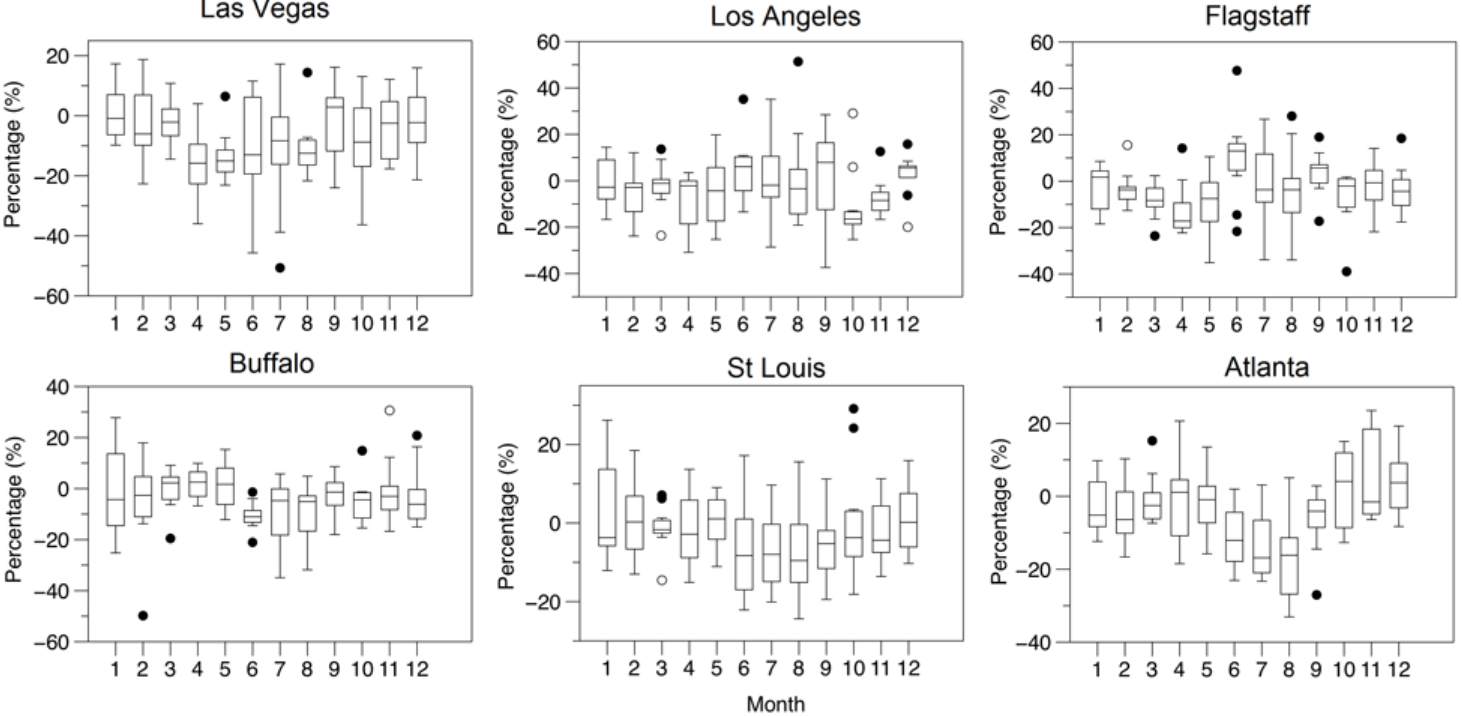

Figure 6. Box Plots of percentage changes of storm duration from 10 individual RCMs.

Percentage changes $(\%)=\left[100\left(\mathrm{SD}_{\text {future }}-\mathrm{SD}_{\text {historic }}\right) / \mathrm{SD}_{\text {historic }}\right]$ where $\mathrm{SD}_{\text {historic }}$ is the ensemble mean storm duration from historic runs and $\mathrm{SD}_{\text {future }}$ is the ensemble mean storm duration from future runs 

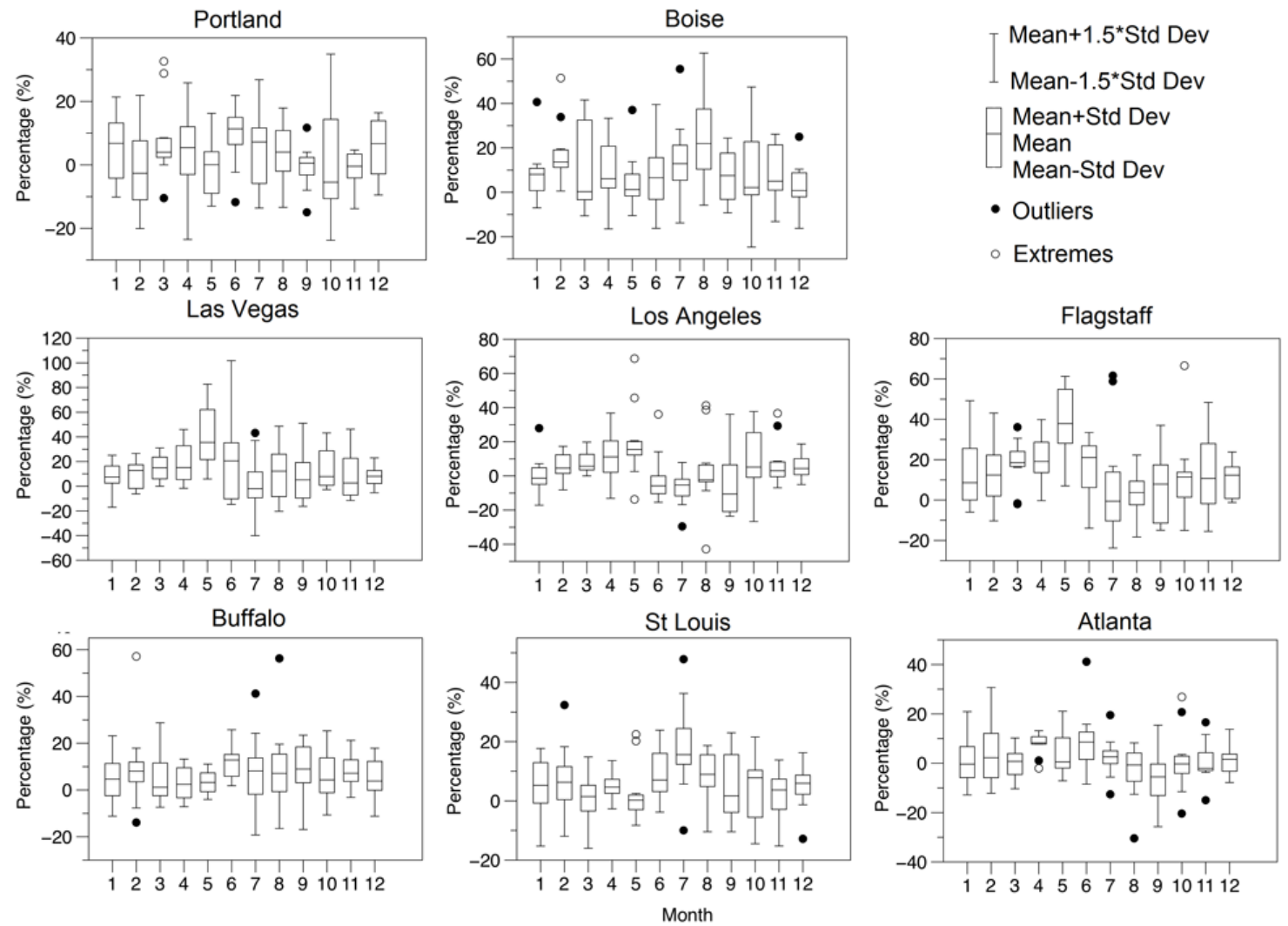

Figure 7. Box plots of percentage changes of inter-storm period from 10 individual RCMs.

Percentage changes $(\%)=\left[100\left(\mathrm{IP}_{\text {future }}-\mathrm{IP}_{\text {historic }}\right) / \mathrm{IP}_{\text {historic }}\right]$ where $\mathrm{IP}_{\text {historic }}$ is the ensemble mean inter-storm period from historic runs and $\mathrm{IP}_{\text {future }}$ is the ensemble mean inter-storm period from future runs 

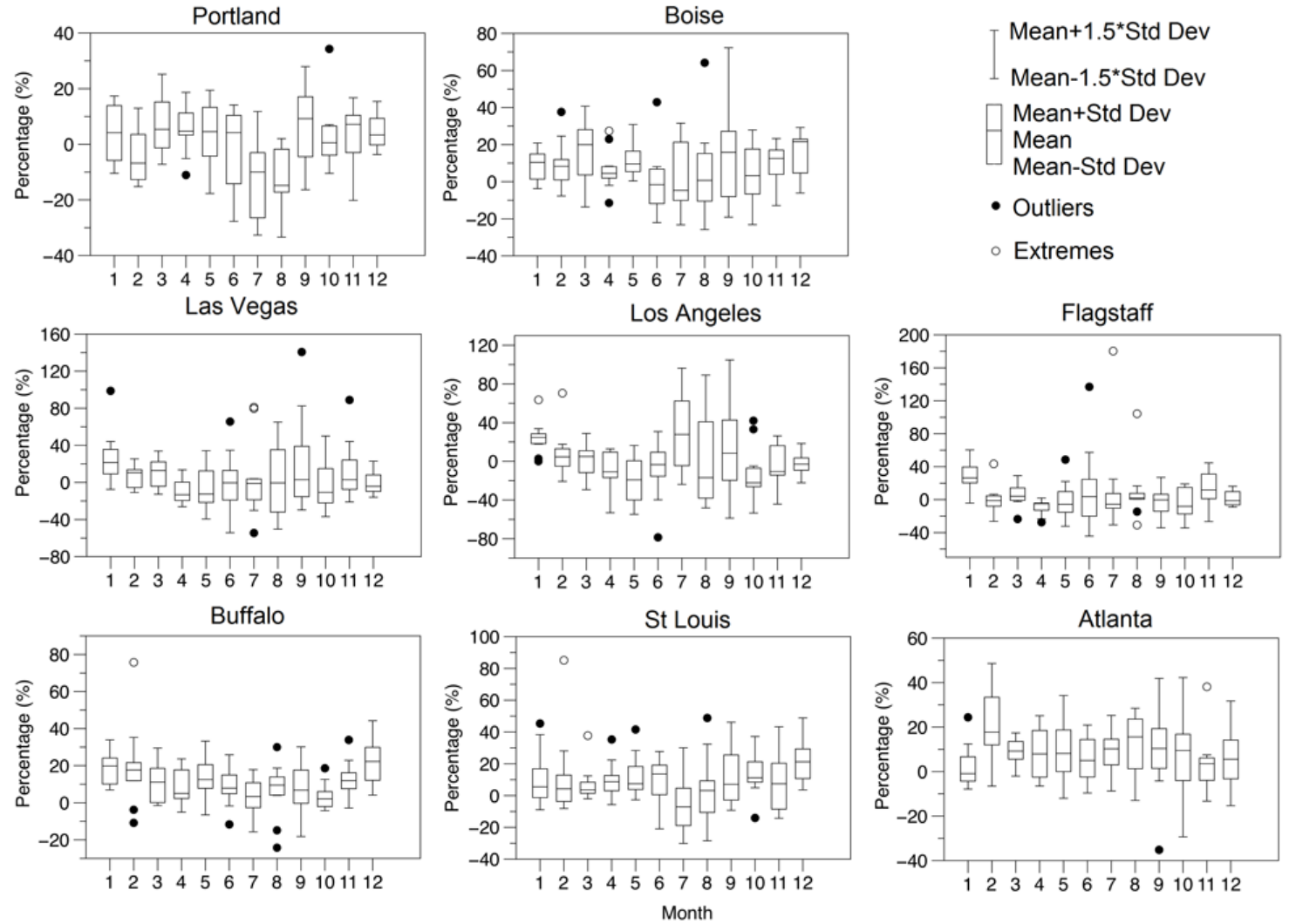

Figure 8. Percentage changes of average storm intensity from 10 individual RCMs.

Percentage changes $(\%)=\left[100\left(\mathrm{SI}_{\text {future }}-\mathrm{SI}_{\text {historic }}\right) / \mathrm{SI}_{\text {historic }}\right]$ where $\mathrm{SI}_{\text {historic }}$ is the ensemble mean storm intensity from historic runs and $\mathrm{SI}_{\text {future }}$ is the ensemble mean storm intensity from future runs 

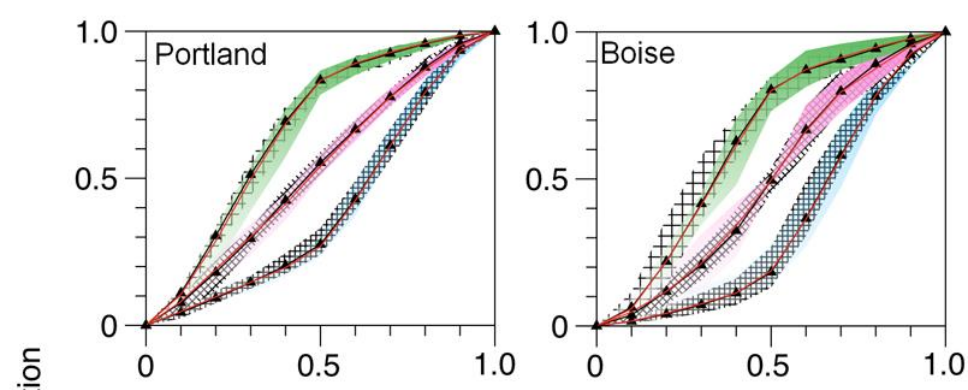

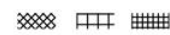

Historic Curve Ranges

Future Curve Ranges

ـ- Mass Curve for Average Historic RCM simulations

- Mass Curve for Average Future RCM simulations
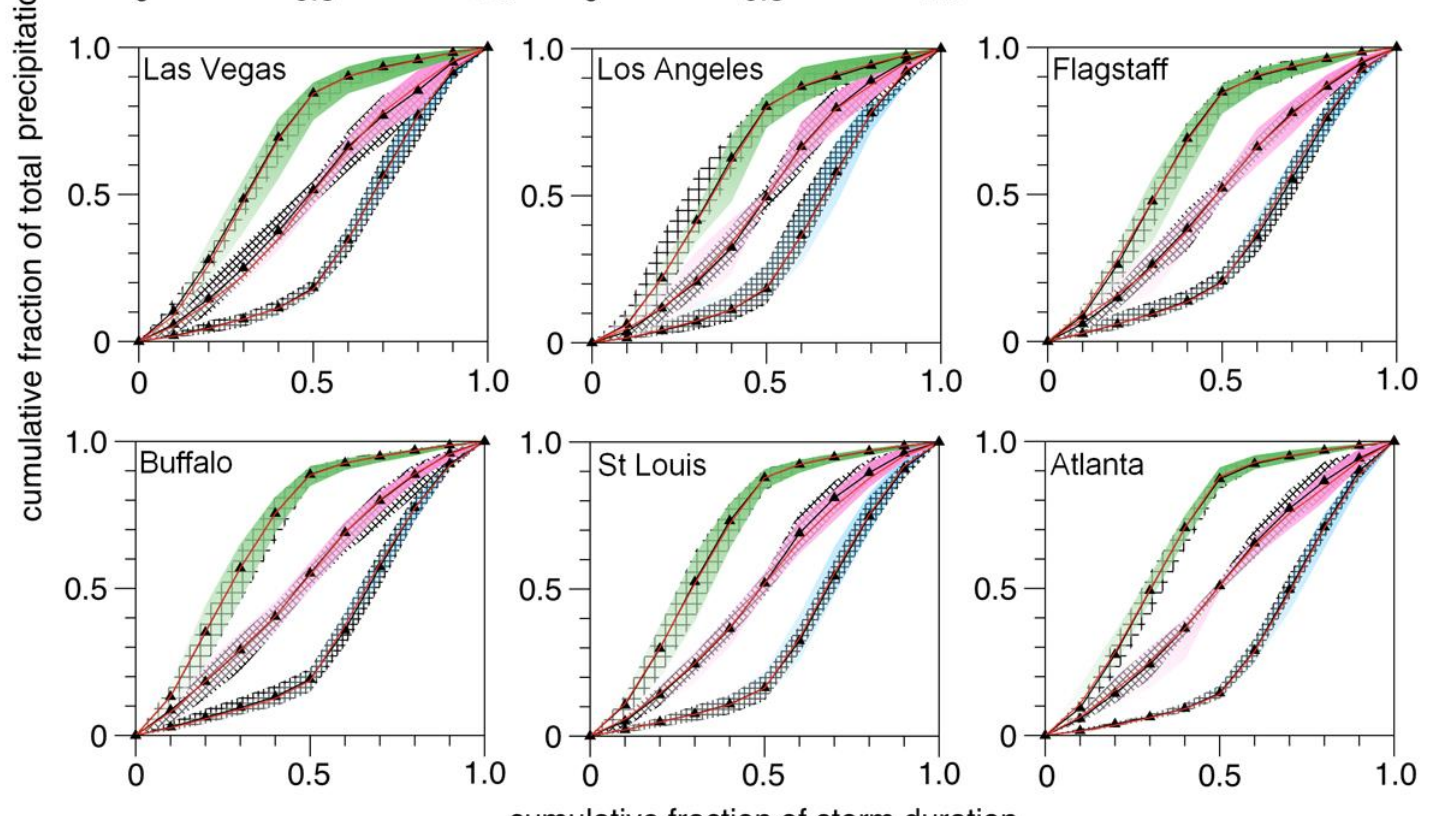

Figure 9. Mass Curves determined from the observed records and 10 NARCCAP RCMsimulated precipitation time series. 


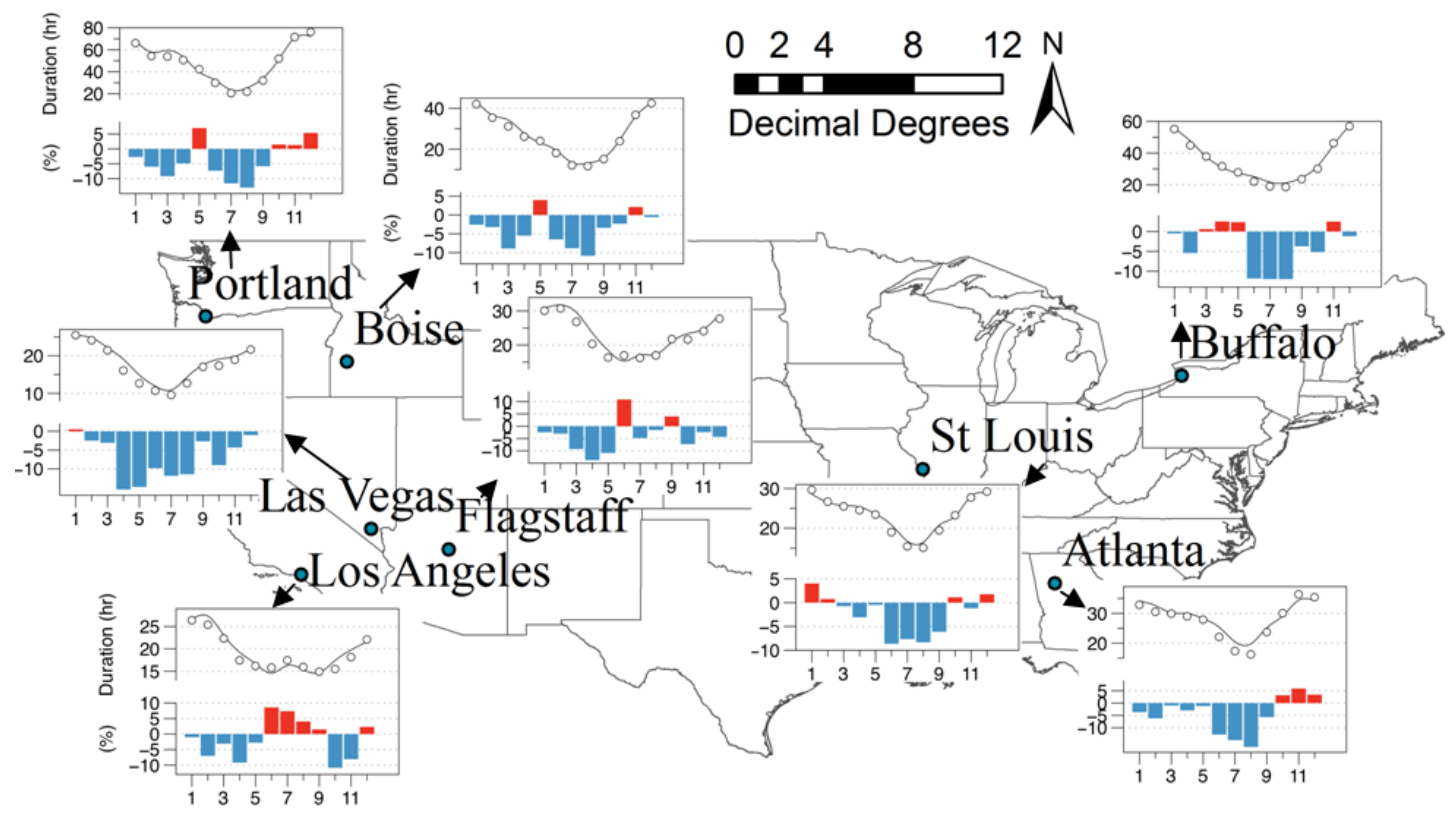

Figure 10. Percentage changes (in \%) of ensemble mean storm duration between historic and future runs. Percentage changes $(\%)=\left[100\left(\mathrm{SD}_{\text {future }}-\mathrm{SD}_{\text {historic }}\right) / \mathrm{SD}_{\text {historic }}\right]$. Lines in the upper axis is $\mathrm{SD}_{\text {historic }}$; circles in the upper axis is $\mathrm{SD}_{\text {future }}$ 


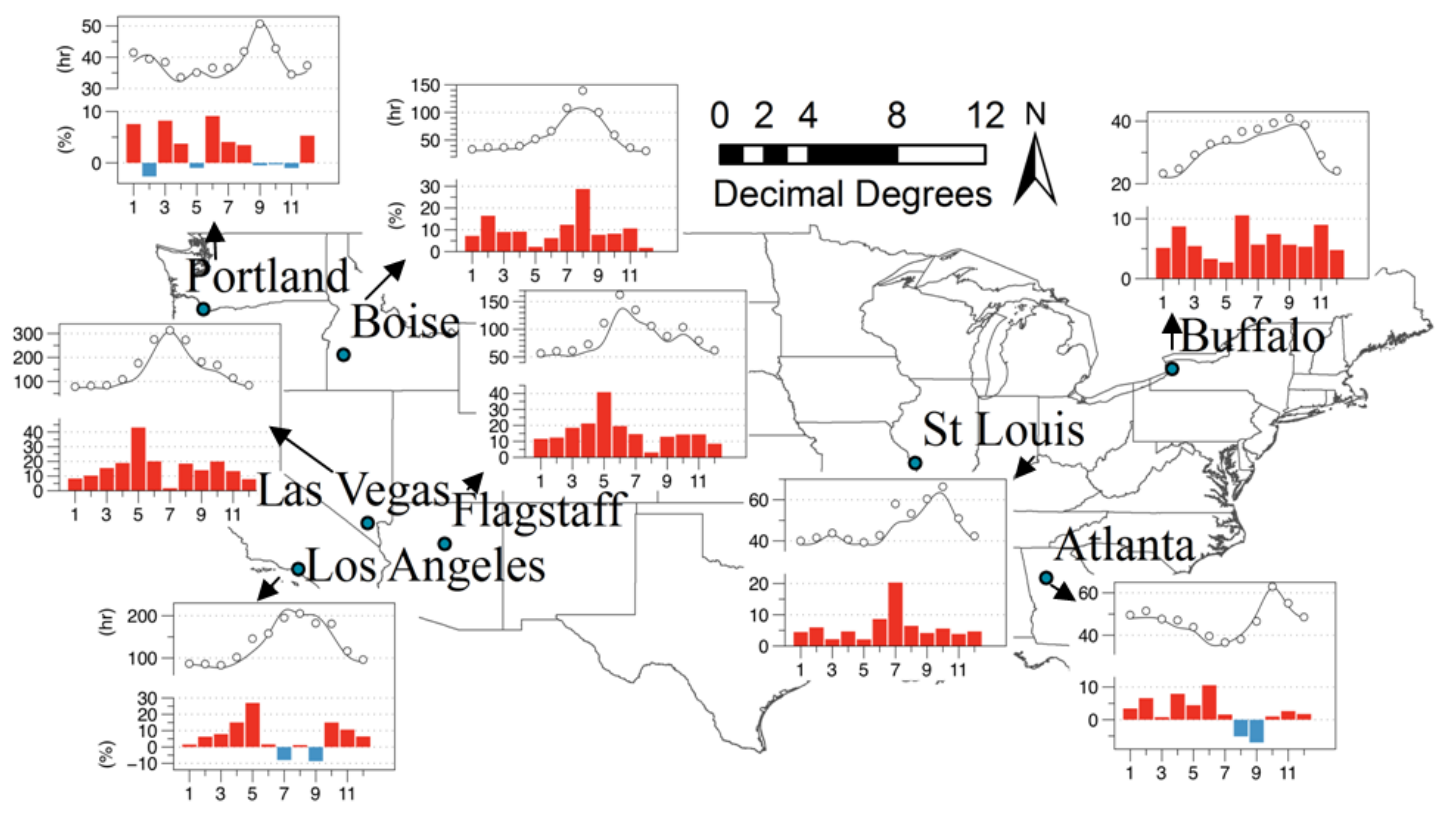

Figure 11. Percentage changes (in \%) of ensemble mean inter-storm period between historic and future runs. Percentage changes $(\%)=\left[100\left(\mathrm{IP}_{\text {future }}-\mathrm{IP}_{\text {historic }}\right) / \mathrm{IP}_{\text {historic }}\right]$. Lines in the upper axis is $\mathrm{IP}_{\text {historic }}$; circles in the upper axis is $\mathrm{IP}_{\text {future }}$ 


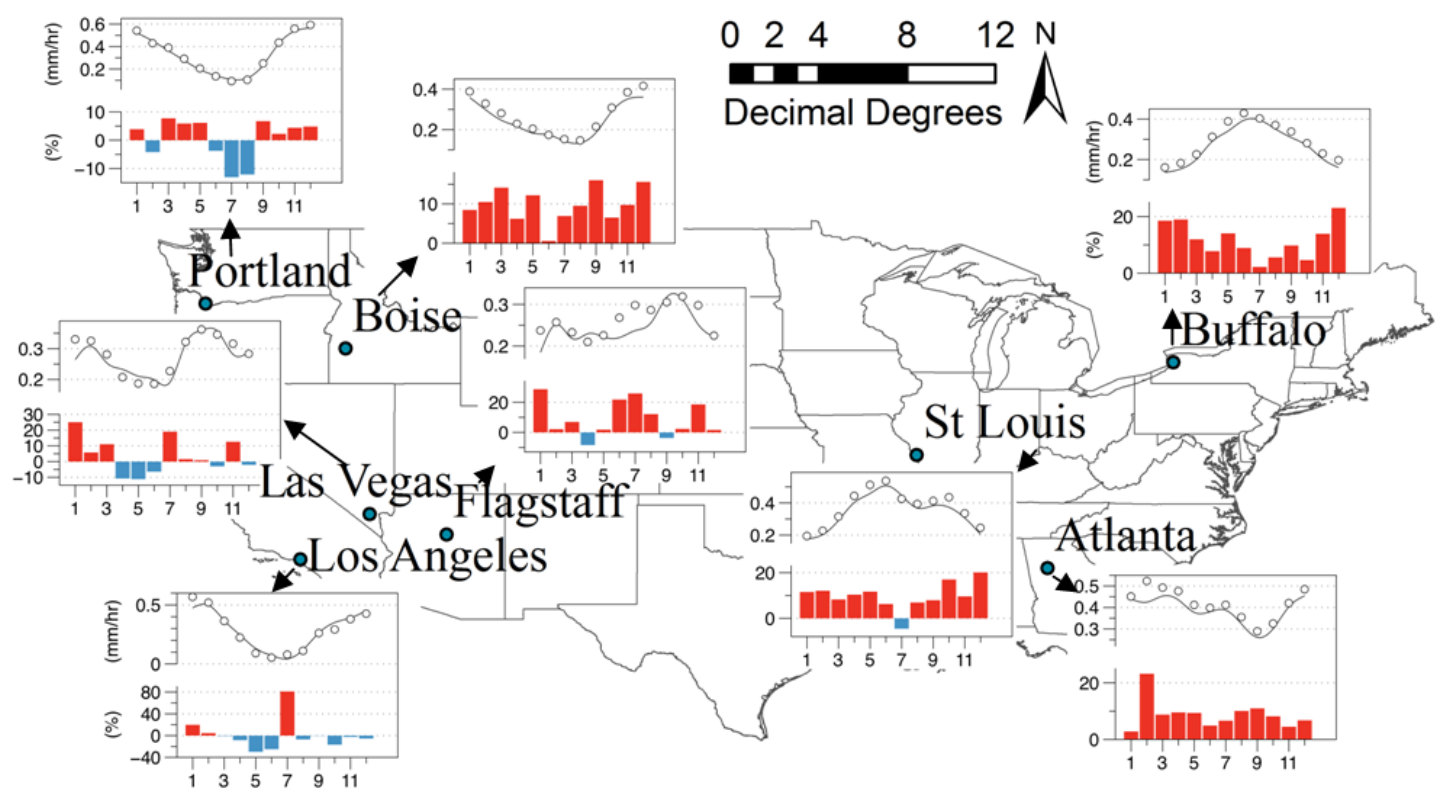

Figure 12. Percentage changes (in \%) of ensemble mean storm intensity between historic and future runs. Percentage changes $(\%)=\left[100\left(\mathrm{SI}_{\text {future }}-\mathrm{SI}_{\text {historic }}\right) / \mathrm{SI}_{\text {historic }}\right]$. Lines in the upper axis is $\mathrm{SI}_{\text {historic }}$; Circles in the upper axis is $\mathrm{SI}_{\text {future }}$ 